University of St. Thomas, Minnesota

UST Research Online

2015

\title{
Who Owns Employee Works? Pitfalls in a Globally Distributed Work Environment
}

\author{
Susan J. Marsnik \\ University of St. Thomas Ethics and Business Law Department, sjmarsnik@stthomas.edu \\ Romain Lorentz
}

Follow this and additional works at: https://ir.stthomas.edu/ocbeblpub

Part of the Business Law, Public Responsibility, and Ethics Commons

This Book Chapter is brought to you for free and open access by the Ethics and Business Law at UST Research Online. It has been accepted for inclusion in Ethics and Business Law Faculty Publications by an authorized administrator of UST Research Online. For more information, please contact asle4660@stthomas.edu. 


\section{Who owns employee works? Pitfalls in a globally distributed work environment}

\section{Susan J. Marsnik and Romain M. Lorentz}

Two seminal questions in any nation's copyright law are: (1) Who has the right to claim authorship and ownership of a copyrighted work; and (2) what is the scope of those interests? Determining who owns a copyrighted work can be complex. In general, the person who creates a copyrightable work is both the author and the first owner of the work.

However, under the United States work-for-hire doctrine, ${ }^{1}$ if an employee creates a work within the scope of employment, the employer is automatically both the author and the owner of the work. Certain statutory categories of commissioned works are also considered works for hire and are subject to similar default authorship and ownership rules. If a work is commissioned from an independent contractor in a category other than a statutory category, the independent contractor remains both the author and the owner, unless the parties agree otherwise by contract.

This is not the legal framework throughout the world. Copyright laws vary substantially from one country to another with little harmonization of key issues such as authorship and ownership. In a multinational context, the differences impact ownership and control of the work in unexpected ways. Thus, for a multinational corporation with employees

* The authors wish to thank Lynda Oswald and Marisa Pagnattaro for organizing the April 2014 colloquium, "Managing the Legal Nexus Among Intellectual Property, Employees, and Global Trade," sponsored by the University of Michigan, Ross School of Business and the University of Georgia, Terry College of Business, and for their efforts editing this work. The authors are grateful to the other participants for their rigorous reading and thoughtful recommendations. Very special thanks to Lee Reer Geffre, University of St. Thomas Law School class of 2015 for her indefatigable research assistance and editing.

1 U.S. Copyright Act, 17 U.S.C. § 101 (1976). 
and contractors located across more than one country, determining who may claim authorship and who owns rights to the work becomes exponentially more complex.

Consider this scenario: A U.S.-based company assembles a team to develop a new smartphone game application (app) consisting of software, graphic art, and music. If every member of the team is a U.S.-based employee hired to complete such work, the company is automatically both the author and the owner of the resulting app. None of the individuals involved in the team has a right to claim authorship and none own any aspect of the copyright. If some of the U.S.-based team are independent contractors, the ownership issues in the commissioned work will depend on whether the piece was commissioned as part of the audiovisual app or separately acquired. ${ }^{2}$ If the music was specially commissioned for the app and the contractor and company executed a work-for-hire agreement, the U.S. company is the author and owner of the application. But if the company purchased an existing piece of music from a non-employee musician, depending on the nature of the contract, the composer could be the co-author and co-owner of the app as a joint work. For the company to own the work outright, the composer would be required to execute an assignment. The company would never be the author of the music, although it could require the composer to waive the right to claim authorship.

As complex as these rules appear under U.S. law, if the team creating the app included individuals located in the United States, France and India, matters of authorship and ownership become even more complicated. Depending on the country in which a particular task is performed, the rights of the U.S. company and the individual hired to complete the work vary considerably. While the United States recognizes corporate authorship, most countries do not. Furthermore, many countries recognize personal rights separate from the economic rights in the work. These moral rights, which include the right to be recognized as the author of the work and the right to object to a distortion or mutilation of the work, cannot be alienated.

2 Video and computer games as a whole and all the component parts of the game application, including the software that operates the program and any audiovisual displays it generates, constitute an audiovisual work for purposes of U.S. copyright law. See Deborah F. Buckman, Annotation, Intellectual Property Rights in Video, Electronic, and Computer Games, 7 A.L.R. Fed. 2d 269, § 4 (2005); Tyler T. Ochoa, Who Owns an Avatar? Copyright, Creativity, and the Virtual World, 14. VAND. J. ENT. \& TECH. L. 959, 969 (2012). 
Failing to understand and address these complexities prior to commissioning the copyrighted work can result in substantial economic impact, if a U.S.-based multinational wrongly assumes that other countries have authorship and ownership rules similar to those in the United States or that U.S. law will apply. Moreover, the conflict of laws rules governing which law will apply to determine authorship, ownership, and liability do not provide clear answers, even if the parties have included a choice of law clause in their agreement.

This chapter does not attempt to provide a comprehensive discussion of variations among foreign laws impacting a work such as the application described above. Rather, it identifies some of the pitfalls facing multinational companies using internationally assembled teams to create copyrighted works. We have chosen a computer game application to illustrate these pitfalls because the game application example allows us to contrast the foreign copyright laws specific to software with more general copyright rules applying to artistic and musical works in those jurisdictions.

The chapter begins with an overview of the U.S. work-for-hire doctrine. We then place authorship and ownership rights in an international context, including the Berne Convention ${ }^{3}$ and the World Trade Organization (WTO) Agreement on Trade Related Aspects of Intellectual Property (TRIPS). ${ }^{4}$ To highlight differences between U.S. laws and the laws of foreign jurisdictions, we consider varying approaches to authorship and ownership in a number of legal regimes, including some of those in which U.S. multinationals might have distributed employees or commissioned contractors. These include a variety of European Union (EU) jurisdictions and India. The chapter analyzes potential conflicts among and between foreign laws, including how courts might choose which law to apply.

\section{AUTHORSHIP AND OWNERSHIP: U.S. COPYRIGHT LAW}

Classifying a work as "made for hire" under U.S. copyright law determines both initial authorship and ownership of the work, the

3 Berne Convention for the Protection of Literary and Artistic Works, Sept. 9, 1886, as revised at Paris on July 24, 1971 and amended in 1979, S. Treaty Doc. No. 99-27 (1986)[hereinafter Berne Convention].

4 Agreement on Trade-Related Aspects of Intellectual Property Rights, Apr. 15, 1994, Marrakesh Agreement Establishing the World Trade Organization, Annex 1C, 1869 UNTS 299; 33 ILM 1197 (1994)[hereinafter TRIPS]. 
duration of the copyright, the owner's renewal, and termination rights. ${ }^{5}$ The contours of the doctrine carry significance not only for employers and employees, but for independent artists, designers, and computer programmers who create commissioned works. Inclusion of the modern work-for-hire doctrine in the Copyright Act of 1976 was meant to ensure predictability in authorship and ownership of the work. ${ }^{6}$

As a starting point, authorship and ownership are distinct concepts in U.S. copyright law. The Copyright Act defines "copyright owner" as "with respect to any one of the exclusive rights comprised in a copyright" the owner of that particular right. ${ }^{7}$ Copyright initially vests in the author. ${ }^{8}$ The Act does not define "author," although it is a term of art throughout the statute ${ }^{9}$ and generally means the person who has fixed the work in a tangible medium of expression. ${ }^{10}$

The exception to the general rule that the author is the person creating the work is the work-for-hire doctrine in copyright. "A work prepared by an employee within the scope of his or her employment" is a "work made for hire." 11 In this situation, the author is not the employee who created the work. Rather, "the employer or other person for whom the work was prepared is considered the author." 12 Thus, the statute incorporates employers into the definition of author. This is not the typical approach to employer ownership in foreign jurisdictions. Congress could have followed a different approach, allowing an employer to gain an ownership interest through assignment, as with patents. Congress could also have granted an automatic transfer of ownership rights by operation of law from the employee to the employer.

Designating the employer as "author" by law possibly reflects a political compromise, ${ }^{13}$ but has advantages. Drafting the Act to include

5 Melville B. Nimmer And David Nimmer, Nimmer ON COPyright $\S 5.03$ [A] (Lslf. ed. 2013) [hereinafter NIMMER].

6 Ibid.

$7 \quad 17$ U.S.C. $\S 101$ (2012).

8 Ibid. $\S 201$ ("Copyright ... vests initially in the author or authors of a work. The authors of a joint work are coowners of copyright in the work.").

9 Catherine L. Fisk, Authors at Work: The Origins of the Work-for-Hire Doctrine, 15) Yale. J. L \& Human. 1, 5 (2003).

10 Case law has defined "author" as "he to whom [a work] owes its origin." Burrow-Giles Lithographic Co. v. Sarony, 111 U.S. 253(1884).

1117 U.S.C. $\$ 101$.

12 Ibid. $\S 201(\mathrm{~b})$.

13 Jay Dratler, JR. And Stephen M. McJohn, Intellectual Property LaW: Commercial, Creative, \& Industrial Property § 6.02 [3][b] (Lslf ed. 2013). 
the employer as an author made revisions easier, since "author" is an otherwise undefined term of art within the Act. ${ }^{14}$ Granting the employer authorship rather than mandating an assignment of ownership circumvented constitutional issues, since the copyright clause provides the exclusive rights belong to the author. ${ }^{15}$ It also ensured that the employer would be the initial owner of the work rather than an assignee, which provides additional rights to the employer. While assignments may be subject to statutory termination or transfer, authorship continues for the life of the copyright. ${ }^{16}$

The work-for-hire doctrine applies to two mutually exclusive categories of works: (1) those created by an employee in the scope of his or her employment and (2) those commissioned from independent contractors in statutorily defined categories of works. Although the U.S. Copyright Act designates the employer as the author and initial owner of works created by employees in the scope of employment, it does not define "employee," "employer," or "scope of employment." The courts have been left to craft tests to define these concepts.

In 1989, the U.S. Supreme Court laid out the framework for analyzing whether a particular work falls within the statutory definition of workfor-hire in Community for Creative Non-Violence v. Reid. ${ }^{17}$ The first step of the analysis requires the court to determine whether the person who created the work is an employee or an independent contractor. Reasoning that Congress used the term "employee" in the context of agency law's master-servant relationship, the Supreme Court adopted common law of agency principles to make the determination. ${ }^{18}$ Courts consider the hiring party's right to control the means and manner through which the work is completed by applying factors such as: the skill required; the source of the instrumentalities and tools; the location of the work; whether the work is part of the hiring party's regular business; the duration of the relationship between the parties; whether the hiring party has the right to assign additional projects to the hired party; the extent of the hired party's discretion over when and how long to work; the method of payment; the hired party's role in hiring and paying of assistants; and the

\footnotetext{
14 Fisk, supra note 9, at 62.

15 US Const. art. I, §8.

16 NIMMER, supra note 5, at $\S 5.03[\mathrm{~B}][2][\mathrm{a}]$ (citation omitted).

17490 US 730 (1989).

18 Ibid. at 739.
} 
provision of employee benefits and the tax treatment of the hired party. ${ }^{19}$ No single factor is determinative ${ }^{20}$ and courts apply the test with varying results. ${ }^{21}$

If the individual is an employee, the second part of the analysis addresses whether the work was within the "scope of employment." If an employee creates a work and the work product produced is not part of his or her employment duties (even though created during working hours using an employer's facilities), the employee retains authorship and ownership of the work. ${ }^{22}$ Conversely, if an employee creates a work off-site that relates to employment duties, it will fall within the scope of employment, with the result being employer authorship. ${ }^{23}$

Parties may alter the default ownership rules of the work-for-hire doctrine by express agreement executed by both the employer and employee. ${ }^{24}$ However, the copyright term differs based on whether the work is an individual work of authorship ${ }^{25}$ or whether it is a work-forhire. ${ }^{26}$ Because the copyright term cannot be modified by the parties, the parties may not contractually vary the employer's legal status as the author. ${ }^{27}$

A second category of work-for-hire rules apply to certain works commissioned from non-employees. The Copyright Act enumerates nine categories of "specially ordered or commissioned works" as works for hire, including works for use as contributions to a collective work as part of a motion picture or audiovisual work, a translation, a supplementary work and instructional text. ${ }^{28}$ If a specially commissioned work falls within one of the enumerated categories, the work-for-hire doctrine applies as long as the parties "expressly agree in a written instrument

19 Ibid. at 751-52, referencing Restatement (SECOND) AGENCY § 220(2) (citations omitted).

20 Ibid. at 752 .

21 See NimmER, supra note 5, at $\S 5.03[\mathrm{~B}][1][\mathrm{a}]$ (analyzing subsequent cases). See also Julian S. Millstein, JefFrey D. NeUgurger and JeFFry P. WEIGARD, DOING BuSINESS ON THE INTERNET: FORMS AND ANALYSIS §3.03[6][a] (Lslf. 2013) (analyzing work-for-hire cases in digital context).

22 NIMMER, supra note 5 , at $\$ 5.03[\mathrm{~B}][1][\mathrm{b}][\mathrm{i}]$.

23 Ibid.

2417 U.S.C. $\$ 201$ (b).

2517 U.S.C. 302(a) (in general, for works created after January 1, 1978, life of author plus 70 years after the author's death).

26 Ibid. \$302(c) (95 years from the date of first publication or 120 years from creation, whichever expires first).

27 NIMMER, supra note 5, at $\$ 5.03[\mathrm{~B}][\mathrm{b}][\mathrm{i}]$.

2817 U.S.C.. § 101. 
signed by them that the work shall be considered a work made for hire." 29 If a work does not fall into one of the statutory categories for commissioned work, it cannot be a work-for-hire. The independent contractor remains the initial author and owner. Any rights transferred to the commissioning party must be expressly set forth in a writing signed by the author/owner of the copyright. Including work-for-hire language for a commissioned work that does not meet the statutory requirements can be detrimental. ${ }^{30} \mathrm{~A}$ copyright assignment is more appropriate. ${ }^{31}$

\section{AUTHORSHIP AND OWNERSHIP: AN INTERNATIONAL CONTEXT}

Approaches to copyright are firmly rooted in historical and national traditions and, as such, vary significantly from country to country. The differing approaches have impacted the development of international copyright law and hindered the adoption of harmonized rules concerning authorship and ownership.

Although broad generalizations can be dangerous, there are similarities concerning features of copyright among common law nations that differ from those in civil law nations. In general, copyright laws in common law jurisdictions favor a utilitarian approach to copyright. In these legal traditions, the rights afforded by copyright tend to be freely alienable and of an economic nature. In the civil law tradition of continental European nations, author rights developed in the context of natural law. In addition to economic rights, these nations have long recognized that authors possess certain inalienable moral rights that stem from a perception of the work as an extension of the author's being. Civil law countries impose restraints on alienability of both economic and moral rights. ${ }^{32}$

29 Ibid.

30 J. Patrick Tober and Shawn C. Helms, The "Work For Hire" Doctrine Almost Never Works in Software Development Contracts, METROPOLITAN CORP. Couns. 10 (June 2008) (If the California Labor Code (Section 3351 5(c)) applies to an independent contractor and the agreement uses work-for-hire language, the company must include the independent contractor under its workers compensation insurance.).

31 Ibid.

32 Paul Goldstein \& P. Bernt Hugenholtz, InTERnational COPYRight: PRinciples, LAW, AND PRACTICE 203 (3d ed. 2012); Richard E. NeFF \& Fran

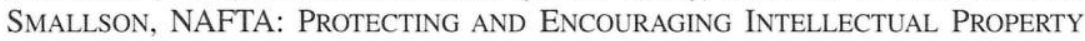
RightS IN NORTH AMERICA 26 (1994). 
National copyright traditions also differ in terms of who may be considered an author. The U.S. position concerning corporate authorship is not typical worldwide. ${ }^{33}$ Civil law countries have historically rejected the principle that legal persons may be authors. ${ }^{34}$

International treaties have become increasingly important as the world moves towards harmonization of intellectual property. For purposes of copyright law, the Berne Convention and TRIPS are the most important to modern national laws. Despite broad harmonization of substantive copyright law through Berne and TRIPS, many areas remain within the domain of national law. Among the areas in which international laws have not achieved harmonization, there are two primary areas of conflict: (1) who is the author and original owner of a work; and (2) whether a nation is obliged to recognize moral rights.

\section{THE BERNE CONVENTION}

The Berne Convention requires its 167 member nations to observe minimum standards for copyright protection, including automatically protecting the works of authors from Berne Convention states within their national boundaries. ${ }^{35}$ Since the United States acceded to the Berne Convention, the Convention has arguably become the most important multinational treaty protecting U.S. nationals under foreign copyright law and vice versa. ${ }^{36} \mathrm{~A}$ number of aspects of the Berne Convention confound adaption of an internationally harmonized work-for-hire doctrine. These include a lack of guidance on issues of authorship and ownership, and mandates that countries observe and enforce moral rights in national law. ${ }^{37}$

33 Other countries do recognize corporate authorship. For example, under Chinese law, if a work is created under the auspices and direction of a legal entity bearing responsibility for the work, authorship resides with the entity. Copyright Law of the People's Republic of China (中华人民共和国著作权法), Art. 11 (promulgated by the Standing Committee of the Eleventh National People's Congress, Feb. 26, 2010, effective Apr. 1, 2010, available at http:// www.wipo.int/wipolex/en/text.jsp?file_id=186569); Xue Hong and Guo Shoukang, China $\S 4$, in InTERnATIONAL Copyright LAW AND PRACTICE (Paul Edward Geller and Lionel Bently eds., 2013).

34 NeFF AND SMallson, supra note 32, at 47.

35 Berne Convention, Art. 5.

36 NIMMER, supra note 5, at $\S 17.04[\mathrm{~B}]$.

37 Much of the tension between moral rights and U.S. copyright law stems from the incompatibility of certain moral rights with the U.S. work-for-hire 
The Berne Convention does not define authorship, provide rules for determining initial ownership in a work, or require countries to recognize legal entities as authors. ${ }^{38}$ Additionally, the Berne Convention does not provide explicit rules for determining the nationality of the author nor choice of law in cross-border disputes. ${ }^{39}$ Determining whether U.S. or foreign law governs matters of authorship and ownership in the area of work-for-hire is made more complex by a lack of international standards. This is particularly true when trying to apply U.S. work-for-hire standards in differing legal environments.

Moral rights, or personality rights, have long been a part of the tradition in continental Europe and many other copyright regimes. The purported international minimum standard for moral rights is expressed in Article 6bis of the Berne Convention, which requires national laws to include the rights of authors to claim authorship (the attribution right), and to object to any distortion, mutilation, or other modification of the work that would be prejudicial to the author's honor or reputation (the integrity right). ${ }^{40}$ Both attribution and integrity rights are at odds with the work-for-hire doctrine.

The United States did not become a contracting party to the Berne Convention until 1988, a century after the Convention was created. The delay was primarily because of moral rights. ${ }^{41}$ The scope of moral rights in the United States is limited, although the United States has taken the

doctrine. See Benjamin S. Hayes, Integrating Moral Rights into US Law and the Problem of the Works for Hire Doctrine, 61 OHIO ST. L.J. 1013, 1014 (2000).

38 The exception is Article 14bis(2), containing special provisions for cinematographic works. GOLDSTEIN \& HUGENHOLTZ, supra note 32, at § 4.4.1.1, 136 (2012). In addition, Article 15(2) has been interpreted as implicitly recognizing corporate authorship in cinematographic works. Robert A. Jacobs, WorkFor-Hire and the Moral Right Dilemma in the European Community: A US Perspective, 16 Boston C. INT'L. \& Comp. L.R. 29, 40 (1993).

39 Goldstein \& HugenholTZ, supra note 32, at § 4.4.1.1, p. 126.

40 Berne Convention, supra note 3, at Art. 6bis(1).

41 The United States has long had concerns that moral rights would impact freedom of contract in copyright industries. The publishing industry was concerned that strong moral rights may cause authors and photographers to assert their integrity rights through litigation and interfere with publication. Producers and distributors were concerned that the cost of sales would increase if they were forced to purchase moral rights in addition to economic rights. NEFF AND SMALLSON, supra note 32, at 17 (discussing U.S. position on moral rights in the context of North American Free Trade Agreements (NAFTA) negotiations). 
position that its common law moral rights and statutory provisions fully comply with Article 6bis. ${ }^{42}$

The Berne Convention is not self-executing in the United States; therefore, authors in the United States do not gain private rights under the treaty. In implementing the Berne Convention, Congress declared that the moral rights provisions of the Berne Convention did not "expand or reduce any right of an author of a work, whether claimed under Federal, State, or the common law," including attribution and integrity rights. ${ }^{43}$ Since moral rights accrue only to natural persons, not legal entities, had the United States not included this declaration, U.S. employees would have gained the right to have their name attach to their work, even though the employer would be considered the legal author of the work. ${ }^{44}$ This may have provided employee-authors with greater recognition and greater bargaining power in employment contexts. ${ }^{45}$ However, industry perspectives prevailed. U.S. creative content industries have long been concerned that moral rights would impact their freedom of contract and increase costs if they were forced to purchase moral rights in addition to economic rights. ${ }^{46}$

\section{TRIPS}

Given the increasing importance of intellectual property-based products to global trade, a primary motivation for including TRIPS in the constellation of WTO side agreements was to ensure all WTO members implemented international minimum standards of intellectual property protection into national law and provided effective national mechanisms for enforcing those rights. TRIPS incorporates the first twenty-one articles of the Berne Convention, but expressly excludes an obligation to incorporate Article 6bis moral rights into national law. ${ }^{47}$

42 Ibid. at 18. The Visual Artist Rights Act of 1990 provides limited moral rights to a small category of visual arts. P.L. No. 101-650 (1990) (codified as amended in scattered sections of 17 U.S.C.). See Hayes, supra note 37, at 1014.

43 The Berne Convention Implementation Act of 1988, Pub. L. No. 100-568, 102 Stat. 2853, Sec.3 (b).

44 Hayes, supra note 37 , at 1027.

45 Ibid.

46 NeFF AND SMALlson, supra note 32, at 19.

47 TRIPS, supra note 4, at Art. 9 (1). 
Despite negotiations so intense as to be described as four and a half years of "bloodletting," 48 TRIPS failed to resolve the authorship/ ownership conundrum nor did it harmonize moral rights. TRIPS contains no standard for establishing authorship nor a standard for who enjoys initial ownership in a copyrighted work. ${ }^{49}$ U.S. efforts to incorporate into TRIPS a transnational work-for-hire rule ensuring employer-author rights failed. Corporate authorship provisions did not survive the final draft of TRIPS. ${ }^{50}$ The exclusion of a moral rights obligation from TRIPS was largely due to pressures from the U.S. ${ }^{51}$

Neither the Berne Convention nor TRIPS has successfully harmonized issues of authorship, ownership and moral rights. This area is rife with pitfalls for businesses that must navigate various rules in different countries. The next section considers how this lack of harmonization has manifested in differing approaches to these issues in national law.

\section{AUTHORSHIP AND OWNERSHIP: THE EUROPEAN UNION}

The legal environment regulating copyright or author rights ${ }^{52}$ in the EU varies substantially from that in the United States. In the United States, copyright is strictly a matter of federal law based in the Constitution. For the twenty-eight EU member states, copyright is partially harmonized though a series of directives. Directives are a form of EU law requiring member states to implement a law that will achieve identified policy and legal goals. National legislatures are obligated to enact national law that meet the minimum requirements of the Directive, but are often allowed to impose additional obligations that do not conflict with the Directive's goals. In this way the law is harmonized, but is not identical across the $\mathrm{EU}$, since implementing laws may differ in key aspects from country to country. Because the underlying historical, social, and cultural issues

48 Ralph Oman, Berne Revision: The Continuing Drama, 4 FORDHAM Intell. PROP., MEdia \& ENT. L. J. 139, 142 (1993).

49 GOLDSTEIN AND HugENHOLTZ, supra note 32 , at $\S$ 4.4.1.1.

50 Oman, supra note 48 , at 143. The United States was successful in negotiating recognition for work-for-hire in the intellectual property provisions of NAFTA. NEFF AND SMALLSON, supra note 32, at 47.

51 NefF AND SMALlson, Ibid. at 33.

52 Many countries designate the law as "author rights," which does have a different theoretical basis. However, for purposes of reading and consistency, we use the term copyright to indicate both. 
impacting copyright vary greatly in different member states, harmonization in key areas has remained elusive.

EU member states take various approaches to authorship and ownership of copyright and differ in their approach to alienation of rights. In general, national laws designate the natural person who created the work as author and initial owner. Exceptions to the rule are more frequent in EU countries with common law regimes than in civil law countries. ${ }^{53}$ Approaches to how an employer comes to own an employee's copyright protected work vary. Some states require express contractual provision to transfer the economic rights to the employer. ${ }^{54}$ Other states' laws imply a transfer of economic rights to the employer by virtue of the employment relationship. ${ }^{55}$ Only one EU member state automatically recognizes the employer as the author and initial owner. ${ }^{56}$

The various national approaches to copyright and author rights within the EU preclude harmonization. At present, no EU directive harmonizes general approaches to authorship and ownership. The few copyright directives that have been implemented are limited to specific issues. ${ }^{57}$ Thus, for the most part, copyright authorship, ownership, and control are matters of unharmonized national law. There is one exception. The 1991 Council Directive $91 / 250$ on the legal protection of computer programs ${ }^{58}$ expressly addresses ownership issues of computer programs. Article 2 (3) provides:

53 Goldstein \& HugENHOLTZ, supra note 32, at 7.

54 AgNÈs LUCAS-SCHLOETTER, “LES DROITS D'AUTEU.R DES SALARIÉS EN Europe CONTINENTALE" 49 - 54 (Cahiers de l'IRPI, No. 5, 2004) (France, Belgium, Romania and Latvia.). Norway).

55 Ibid. at 35-48 (Germany, Austria, Italy, Sweden, Denmark, Finland,

56 Ibid. at 10 (The Netherlands).

57 For example, in 2001, the EU adopted a Directive on the Harmonisation of Certain Aspects of Copyright and Related Rights in the Information Society, Directive 2001/29/EC of the European Parliament and of the Council of 22 May 2001 on the Harmonisation of Certain Aspects of Copyright and Related Rights in the Information Society, 2001 O.J. (L. 167) 10. It did not address the work-for-hire question. Neither was the issue raised in the recent Directive on collective management of copyright and related rights and multi-territorial licensing. Directive 2001/29/EC of the European Parliament and of the Council of 22 May 2001 on the Harmonisation of Certain Aspects of Copyright and Related Rights in the Information Society, 2001 O.J. (L. 167) 10.

58 Council Directive 1991/250/EEC on the Legal Protection of Computer Programs, 1991 O.J. (L 122) 42 [hereinafter Computer Program Directive]. See also Alan K. Palmer and Thomas C. Vinje, The EC Directive on the Legal Protection of Computer Software: New Law Governing Software Development, 2 
Where a computer program is created by an employee in the execution of his duties or following the instructions given by his employer, the employer exclusively shall be entitled to exercise all economic rights in the program so created, unless otherwise provided by contract. ${ }^{59}$

The Directive's approach is similar to the U.S. work-for-hire doctrine in that the economic rights vest in the employer. However, it differs in that it addresses ownership and not authorship. In the United States, the employer would be both author and owner of the work. National copyright law in a particular EU member state will govern who is considered to be the author of a computer program. Computer programs are not sui generis rights. ${ }^{60}$ They exist within the contours of copyright law, ${ }^{61}$ but are treated differently than other works.

Furthermore, the Computer Program Directive expressly addresses only economic rights and not the moral rights vested in the work. Moral rights are not harmonized in the EU. ${ }^{62}$ States take differing approaches to both the scope of moral rights and how an author's interests may be transferred.

For example, France takes a dualist approach to economic and moral rights. While the economic rights are freely alienable in France, moral rights are "perpetual, inalienable and imprescriptible."63 In Germany and Austria, economic and moral rights are considered to be so thoroughly

DukE J. COMP. \& INT'L. L. 65 (1992) (general analysis of Computer Program Directive requirements).

59 Computer Program Directive, ibid. at Art.(2) (3).

60 Marc. A. Ehrlich, Fair Use or Foul Play? The EC Directive on the Legal Protection of Computer Programs and Its Impact on Reverse Engineering, 13 PACE L. REV. 1003, 1007 (1994) (proposals for the directive rejected a sui generis approach].

61 For example, under French law, computer programs are listed as a "work of the mind" CODE DE LA PROPRIÉTÉ INTELLECTUELLE [CPI] Art. L.121-2. Art. L.122-6 (Fr.), available in English at www.legifrance.gouv.fr/content/download/ 1959/13723/.../Code 35.pdf [hereinafter French Copyright Code). Under German Law computer programs are considered literary works. Gesetz über Urheberrecht und verwandte Schutzrechte [Urheberrechtsgesetz] [Copyright Act], Sept. 09, 1965, BGB1. I S. at 1273, Art. 2(1) (1.)(Ger.), available in English at http:// www.iuscomp.org/gla/statutes/UrhG.htm [hereinafter German Copyright Act].

62 Hayes, supra note 37, at 1019 (citing Council Directive 93/98/EEC of 29 Oct. 1993 harmonizing the term of protection of copyright and certain related rights, Preamble, para.4 exempting moral rights from harmonization).

63 GoldSTEIN AND HugENHOLTZ, supra note 32, at 254. 
intertwined that the economic right may only be alienated through the grant of a privilege to use the work. ${ }^{64}$ United Kingdom (UK) law prohibits assignment of moral rights, ${ }^{65}$ but permits authors to waive them. ${ }^{66}$ What follows is a brief overview of the copyright regimes in three EU member states to illustrate the different approaches taken and the lack of overall harmony.

\section{A. France}

In French law, only natural persons who create a work of the mind may be authors. ${ }^{67}$ There can be no corporate authorship, although a legal entity may own the copyright through express or implied agreement. In the case of software, the transfer of ownership is implied at law. The author enjoys "an exclusive incorporeal property right which shall be enforceable against all persons" which includes both moral and economic rights. ${ }^{68}$ Thus, ownership vests in the author. French law grants moral rights beyond the minimum required by Article 6bis of the Berne Convention. In addition to the rights of attribution and integrity, French authors possess the right of divulgation (the right to decide when and how a work is disclosed to the public) ${ }^{69}$ and a right of retraction (the right to recover the exploitation rights in the work)..$^{70}$ Moral rights are

64 Ibid. at 265 (the privilege is similar, but not identical to licenses in other countries).

65 Copyright, Designs and Patent Act, c.V, §94 (1988) [hereinafter, U.K. Copyright Act].

66 U.K. Copyright Act, c.IV, $\S 87(2)$ (the waiver is in writing and signed by the person giving up the right).

67 André Lucas, Pascal Kamina and Robert Plaisant, France §4[1], in InTERNATIONAL COPYRIGHT LAW AND PRACTICE (Paul Edward Geller and Lionel Bently eds. 2013).

68 French Copyright Code, supra note 61, at Art. L. 111-1.

69 Ibid. at Art. L. 121-2; Lucas, et al., supra note 67, at §7[1][a] (divulgation requires a concrete act of disclosure by the author and encompasses the right to not disclose the work).

70 French Copyright Code, supra note 61, at Art.L.121-4; Lucas, et al., supra note 67 , at $\S 7[1][\mathrm{d}]$ (the author may recover exploitation rights in the work that have been transferred, providing he indemnifies the transferee). 
perpetual, ${ }^{71}$ inalienable ${ }^{72}$ and subject to limitations concerning whether they may be waived. ${ }^{73}$

These rules apply generally in an employment context. Article L.111-1 provides that "the existence or conclusion of a contract for hire or of service" does not impact an author's rights. ${ }^{74}$ An employment contract is a contract of service. ${ }^{75}$ Copyright vests initially with the authoremployee, even if it is created at the direction of the employer. French law does not imply an automatic transfer of ownership of economic rights to the employer or the commissioning party.

Assignments are allowed, but will only be enforced if the assigned rights are expressly mentioned in a written agreement and comply with the formal requirements of the French Intellectual Property Code, including that each is defined as to scope and purpose, place and duration. ${ }^{76} \mathrm{An}$ assignment clause whose terms are too general and broad may be invalidated. ${ }^{77}$ Because French law prohibits the total transfer of future works, ${ }^{78}$ employers in France not only include a clause in employment agreements transferring rights from the employee author, but regularly revise and update to refer precisely to specific employee works to ensure the validity of the transfer clause.

In compliance with the Computer Program Directive, different rules apply to software created on the job. Article L. 113-9 provides: "[u]nless otherwise provided by statutory provision or stipulation, the economic rights in the software and its documentation created by one or more

71 French Copyright Code, ibid. at Art. L. 121-1; Lucas, et al., Ibid. at $\S 7[3]$ (the French Copyright Code is silent on the duration of divulgation rights, but it is assumed these rights are perpetual, however doubts exist as to the duration of the right of retraction).

72 French Copyright Code, ibid. at Art. L. 111-1.

73 Lucas, et al., supra note 67, at $\$ 7[4][b][i]$ and [ii] (an author may temporarily renounce the right of attribution, but it is questionable whether that may be done in favor of another person; the integrity right may be limited by agreement and an author may authorize modifications to the work after they have been made).

74 French Copyright Code, supra note 61, at Art. L. 111-1(2).

75 Lucas, et al., supra note 67, at $\$ 4[\mathrm{~B}][\mathrm{ii}][\mathrm{A}] 5$.

76 Cour de cassation [Cass.] [Supreme court for judicial matters] Jul. 12, 2006, Bull. civ., No. 5-15472 (Fr.). See also, Lucas, et al., supra note 67, at $\S 4[\mathrm{ii}][\mathrm{B}]$ (explaining that while some cases have held a "pre-assignment" in an employment contract to include a transfer of all rights created on the job to the employer, such findings contradict the letter and spirit of the law).

77 French Copyright Code, supra note 61, at Art. L. 131-3.

78 Ibid. at Art. L. 131-1. 
employees in the execution of their duties or following the instructions given by their employer shall be the property of the employer and he exclusively shall be entitled to exercise them." ${ }^{79}$ Economic rights in employee software automatically transfer to the employer by operation of law. The employer is not the original owner of the work, but a transferee who retains economic rights even after the employee is no longer working for the company. ${ }^{80}$ The employee remains the author and possesses limited moral rights. The author may not oppose modification of the software by the employer if the modification does not prejudice either his honor or his reputation, and he may not exercise his right of retraction. ${ }^{81}$

\section{B. Germany}

German copyright law shares some commonalities with French copyright law, but also differs substantially. The German Copyright Act declares that authors "shall enjoy protection for their works." 82 An author, who is also the initial owner, can only be the natural person who created the work. ${ }^{83}$ This includes works made as part of employment or specially commissioned. German law does not recognize a legal entity's ability to initially own a copyright. ${ }^{84}$

German law recognizes both moral and economic rights. But, unlike French law, which treats these rights separately, German law takes a monistic approach. According to this theory of copyright, economic and moral rights are inseparable, because economic rights may serve the author's personal interests and moral rights may serve his financial interests. ${ }^{85}$ Unlike French law, moral rights are not perpetual, but are subject to the same term as economic rights. ${ }^{86}$ German moral rights are broader than what is required by Article 6bis of the Berne Convention. Statutory rights include the rights of attribution, integrity, divulgation

79 Ibid. at Art. 113-9.

80 Lucas, et al, supra note 67, at $\S 4[\mathrm{D}]$.

81 French Copyright Code, supra note 61, at Art. L. 121-7.

82 German Copyright Act, supra note 61, at Art. 1.

83 Ibid. at Art. 7; see also Adolf Dietz, Germany §4][1][a], in INTERNATIONAL COPYRIGHT LAW AND PRACTICE (Paul Edward Geller and Lionel Bently eds. 2013)(for discussion of authorship issues in joint works).

84 Dietz, ibid.

85 Ibid. at $\S 4[2][\mathrm{a}]$ and $\S 7[1]$.

86 German Copyright Act, supra note 61 at, Art. 64 (copyright expires 70 years after the author's death). 
(publication), retraction and the right to access the work. ${ }^{87}$ German moral rights also incorporate general rights of personality beyond those enumerated in the German Copyright Act. ${ }^{88}$

Germany's monistic approach fuses economic and moral rights into an inseparable, inalienable bundle. German law has no provision equivalent to an assignment or license under U.S. law. Indeed, German law precludes transfer of copyright (with the exception of testamentary dispositions $)^{89}$ to protect authors from being deprived of core rights through contractual transfers. ${ }^{90}$ Authors may only exploit their work through a grant of a privilege to use the work. ${ }^{91}$ This exploitation right, or Nutzungsrechte, approximates an exclusive or nonexclusive license in other legal traditions. ${ }^{92}$ But it does not grant an ownership interest. In general, contracts granting the exploitation right do not have to be in writing, with the exception that agreements granting rights in future works must be in writing and may be terminated by either party after five years. ${ }^{93}$

Article 43 of the German Copyright Act mandates these rules to apply both to works created by employees under contracts for employment and to a contract commissioning services. ${ }^{94}$ German law contains no general work-for-hire concept in which initial ownership of the copyrighted work vests in the employer or commissioning party. ${ }^{95}$ Article 43 does not create a presumption of transfer to the employer. Such transfers are possible but they must be provided for by contract. ${ }^{96}$ The final clause of Article 43 supports this by stating "provided nothing to the contrary transpires from the terms or nature of the contract of employment or

87 Ibid. at Arts. 13, 14, 12(1) 41 and 25. For discussion of the contours of each of the rights and limitations, see Lucas, et al., supra note 67, at $\$ 7$.

88 Dietz, Ibid. at $\S 7[1]$ (rights of personality protected by the German Constitution are recognized as part of copyright law).

89 German Copyright Act, supra note 61, at Art. 29.

90 Dietz, supra note 83 , at $\$ 4[2][a]$.

91 German Copyright Act, supra note 61, at Art. 31; Dietz, supra note 83, at $\S 4[2][a]$.

92 Goldstein And Hugenholtz, supra note 32, at 265; Dietz, supra note 83 , at $\$ 4[2][a]$.

93 German Copyright Act, supra note 61, at Art. 40(1).

94 Ibid. at Art. 43.

95 Dietz, supra note 83, at $\S 4[1][\mathrm{b}]$.

96 LUCAS-SCHLOETTER, supra note 54, at 24-34 (the same rebuttable presumption is the rule in Spain, Portugal, Slovenia, Slovakia and Albania). 
service."97 At times, courts have interpreted this "vague and unsatisfactory clause" to find implied clauses in favor of employers. ${ }^{98}$ However, the transfer will be only of exploitation rights, and not ownership.

Pursuant to Germany's implementation of the Computer Program Directive, the rules differ when the work is a computer program. Article $69 \mathrm{~b}$ (1) of the German Copyright Act provides: "Where a computer program is created by an employee in the execution of his duties or following the instructions given by his employer, the employer exclusively shall be entitled to exercise all the economic rights in the program, unless otherwise agreed." 99 This section creates a stronger presumption of transfer of exploitation rights. ${ }^{100}$ However, read in light of Germany's monistic tradition, the article limits the presumption: the employer is granted the exclusive right to exercise the economic rights in the software created by the employee, but the employee remains the author and owner of the rights.

\section{United Kingdom}

The United Kingdom, in the common law tradition, takes a more utilitarian approach to copyright, historically placing less emphasis on moral rights than its civil law counterparts. Under the U.K. Copyright Act, "author" is defined as "the person who creates" the work. ${ }^{101}$ Unlike U.S. law, which allows for corporate authorship, U.K. law requires the author be a "flesh and blood" person. ${ }^{102}$ Original ownership vests with the author, subject to exceptions for employment, Crown and Parliamentary copyright, and copyright held by certain international organizations. ${ }^{103}$ Although U.K. law does not have a general work-for-hire provision, Article 11(2) of the U.K. Copyright Act provides that: "[w]here a literary, dramatic, musical or artistic work is made by an

\footnotetext{
97 German Copyright Act, supra note 61, at Art. 43.

98 Dietz, supra note 83 , at $\S 4[1][\mathrm{b}]$ (citation omitted).

99 German Copyright Act, supra note 61, at Art. 69b (1).

100 Dietz, supra note 83 , at $\$ 4[1] \mathrm{b}]$.

101 UK Copyright Act, supra note 65, at c.48, p.I, § 9; Lionel Bentley and William R. Cornish, United Kingdom \$4[1], in INTERNATIONAL COPYRIGHT LAW AND PRACTICE (Paul Edward Geller \& Lionel Bently eds., 2013) (The statute recognizes that authorship in various categories of works may be a person other than the one who created the work. For example, in the case of a film, the producer and principal director are the author.).

102 Bentley and Cornish, ibid. (Special rules and presumptions apply to various categories of work, including computer-generated work.).

103 U.K. Copyright Act, supra note 65, at c.48, p I, § 11.
} 
employee in the course of his employment, his employer is the first owner of any copyright in the work subject to any agreement to the contrary." 104 Computer software is protected as a literary work.

By operation of law, ownership of an employee's work in those categories automatically vests in the employer unless the parties agree otherwise by contract. ${ }^{105}$ The U.K. approach thus contrasts with the general approach in France and Germany, although other European countries have a similar approach to economic rights automatically vesting in the employer. ${ }^{106}$

To determine whether the employer exception applies, U.K. courts must determine whether an employment relationship exists and whether the work was created in the scope of employment. The first part of the test focuses on whether there is "mutuality of obligations" in which the employer is obligated to provide paid work and the employee to provide labor. ${ }^{107}$ The employer must also be able to exercise control over the employee. ${ }^{108}$

Even if an employment relationship exists, the legal presumption applies only if the work was within the scope of the employee's duties. ${ }^{109}$ As with the U.S. work-for-hire doctrine, whether the work was created outside the work place and office hours is not determinative of whether the work was created in the scope of employment. ${ }^{110}$ If the work is commissioned from an independent contractor, copyright ownership may be assigned, as long as it is in a signed writing. ${ }^{111}$

Although the United Kingdom acceded to the Berne Convention in 1887, it did not recognize statutory moral rights until 1988. Chapter IV of the U.K. Copyright Act codifies the Berne Convention Article 6bis rights of attribution and integrity. ${ }^{112}$ These statutory rights are complex in terms of how they relate to particular works and numerous exceptions

104 Jacobs, supra note 38, at 69.

105 SANNA WOLK AND CHRISTINE KirchBERgER, OWNERSHIP OF THE COPYRIGHT IN WORKS AND THE PATENT Right IN INVENTIONS CREATED BY EMPLOYEES: In Finland, Sweden, Germany, Austria, THE United Kingdom, Estonia AND ARGENTINA 16 (2002).

106 LUCAS-SCHLOETTER, supra note 54, at 10-23 (Poland, Hungary, Lithuania, Estonia, the Czech Republic, Greece, Bulgaria and Croatia).

107 Bentley and Cornish, supra note 101, at $\S 4[1][\mathrm{b}]$ (citations omitted).

108 Ibid.

109 Ibid. at $\S 4[1][\mathrm{b}]$.

110 Ibid.

111 U.K. Copyright Act, supra note 65, at c.48, p. 1, §90(3).

112 Ibid. at c. 48, p. $1, \S \S 77$ and 80 . The statute also recognizes a right against false attribution ( $\$ 84)$. 
exist. For example, the right to claim authorship does not apply to works where ownership originally vests in the employer ${ }^{113}$ or to computer programs. ${ }^{114}$

The right of integrity does apply to works created in the scope of employment, ${ }^{115}$ but does not apply to anything done in relation to the work by the copyright owner. ${ }^{116}$ Moral rights may not be assigned ${ }^{117}$ but they may be waived in a signed writing. ${ }^{118}$

This section demonstrates that even within the EU, which has harmonized certain aspects of copyright, issues of ownership and moral rights diverge greatly.

\section{AUTHORSHIP AND OWNERSHIP: INDIA}

As a Commonwealth nation whose legal system developed from the English common law, India's approach to copyright has its roots in the English, utilitarian approach. ${ }^{119}$ Indian copyright is governed by the Copyright Act of 1957 as amended by the 2012 Bill. 120 "Author" is defined particularly as it relates to various categories of works. For literary works, including computer programs, "author" is tautologously defined as "the author of the work."121 The author is the natural person who created it. ${ }^{122}$ There is no provision in the Indian Copyright Act for

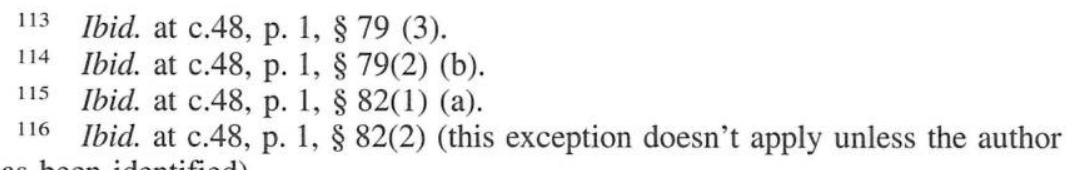
has been identified).

117 Ibid. at c. 48 , p. $1, \S 94$.

118 Ibid. at c.48, p. 1, §8; Bentley and Cornish, supra note 101, at $\S 7[4]$ (moral rights may also informally waived under contract law or estoppel).

119 The rationale for protecting creative works is that economic and social development of society are dependent upon them. India: A Handbook of Copyright Law (Government of India Ministry of Human Resource Development) (1999) available at http://www.wipo.int/wipolex/en/text.jsp?file_id= 208016.

120 The Copyright Act, 1957 No. 14 of 1957; India Code (1957), available at http://www.wipo.int/wipolex/en/text.jsp?file_id=128098 [hereinafter, Indian Copyright Act].

121 Ibid. at $\S 2$ (d) (i).

122 Dev Gangjee and S. Ramaiah, India §4[1], in INTERNATIONAL COPYRIGHT LAW AND PRACTICE (Paul Edward Geller and Lionel Bently eds. 2013). 
corporate authorship. In most instances, the first owner of the work is the author, subject to exceptions).

Article 17 (c) presentsa general provision akin to work-for-hire by providing that initial ownership of a work created in the course of employment "under a contract of service" shall vest in the employer, unless the parties agree otherwise. ${ }^{123}$ The contract of service refers to an employment agreement. Key in determining whether the employment relationship exists is the degree of control the employer is entitled to exercise. ${ }^{124}$

These ownership provisions do not apply to works created under a "contract for service," such as that with an independent contractor. ${ }^{125}$ If the work is commissioned from an independent contractor, Section 18(1) of the Act allows the owner to license or assign the rights attached to his work, including future works. ${ }^{126}$ Section 19 imposes formalities and requirements, including a signed writing specifying the rights assigned, duration, and territorial extent of the assignment. ${ }^{127}$ Indian law is not clear as to whether it is possible to assign or license the entire copyright without a limitation of term or territory, making the effectiveness of an assignment potentially problematic. ${ }^{128}$

The Indian Copyright Act recognizes the moral rights of attribution and integrity as "special rights" 129 that exist independently of copyright. ${ }^{130}$ An author retains these rights even after the work has been assigned. Moral rights cannot be assigned. The statute provides that an author is entitled to an injunction or damages for the distortion, mutilation, modification, or other act prejudicial to the work. ${ }^{131}$ India is

123 Indian Copyright Act, supra note 122 , at $\$ 17$ (c).

124 Ibid.

125 Indian courts have made the distinction between contracts of service, referring to employment, and contracts for service, to avoid applying this provision to independent contractors. Gangjee and Ramaiah, supra note 122, at $\S 4[1][\mathrm{b}][\mathrm{i}]$ (citations omitted); see also MichaEL A. EPSTEIN AND FRANK L. Politano, Drafting Licensing AGREEMENTS §17.02[B][1] (2002, 2003 SupPLEMENT).

126 Indian Copyright Act, supra note 120, at $\S 18(1)$.

127 Ibid. at $\S 19(1)$. There are further provisions limiting the assignment, including requirements that the assignee must exercise the rights $(\S 19(4))$ and that the assignment will be limited to five years, unless a different term is indicated $(\S 10(5))$.

128 EPSTEIN AND Politano, supra note 125, at \$17.02[B][1].

129 Indian Copyright Act, supra note 119, at $\$ \S 57$ (1) (a) and (b).

130 Ibid. at $\S 57(1)$.

131 Ibid. at $\S 57(1)(\mathrm{b})$. 
"unique among common law countries" in how it deals with computer programmer moral rights. ${ }^{132}$ Indian copyright contains a 'fair use' exception to infringement for copying or adapting a computer program for noncommercial purposes by the lawful owner of that copy. ${ }^{133}$ The author of a computer program does not possess a right to enjoin or claim damages for the exercise of this exception. Normal use of a computer program by a purchaser will not be an infringement of moral rights. Indian law is unclear as to what extent an employer or commissioner of a software program will be exempt from liability for violation of the right of integrity. ${ }^{134}$ Nor is it clear whether subsequent development of a software program by an employer or one who has commissioned the work would be violation of the programmer's moral rights. ${ }^{135}$ The Indian statute is silent on whether moral rights may be waived and case law is inconclusive. ${ }^{136}$

\section{CONFLICT OF LAWS: WHICH LAW DETERMINES AUTHORSHIP AND OWNERSHIP?}

Companies developing copyright protected products are concerned with retaining ownership and control over those products. In the U.S., ownership and control are facilitated by the work-for-hire doctrine which guarantees a great deal of control. Navigating copyright issues with a globally distributed workforce of employees or independent contractors is much more complex. The company must understand the contours of copyright law in each country in which a portion of the work is completed to better ensure ongoing ownership and control of the work.

The smartphone game application illustration presented early in the chapter demonstrates the complex nature of operating with a globally distributed workforce. Suppose the team includes a U.S. employee creating the graphics, a French employee composing the music, and an Indian employee designing the software. Under this scenario, by operation of law the U.S. employer is author and owner of the graphics, but may not legally be the sole author of the entire application. Given the

\footnotetext{
132 Mira T. Sundara Rajan, Moral Rights: Principles, Practice and New TEChNOLOGY 295 (2011).

133 India Copyright Act, supra note 120, at § 52(1) (aa).

134 RAJAN, supra note 132, at 296.

135 Ibid.

136 Nandita Saikia, Indian Law: Getting Moral Rights Waived (July 15, 2012) available at http://copyright.lawmatters.in/2010/07.
} 
contours of French and Indian law concerning authorship, it is possible that the work would be one of joint authorship. ${ }^{137}$ Without appropriate agreements, the company may not even own the economic aspects of components of the work created abroad. Under French copyright law, the composer, whether an employee or independent contractor, is the author. The composer may assign economic rights, subject to formalities and limitations, but is prohibited from assigning or waiving moral rights. The French composer will retain the right to claim authorship and object to a modification to the music that infringes his integrity right. If a French employee had created the software, the economic rights automatically transfer to the employer. In contrast, a French employee software developer, remains the author and retains limited moral rights.

Different rules apply to the software portion of the application created by an employee in India. Under India's version of work-for-hire, the employer is the first owner of the copyright, regardless of whether the employee creates the music, graphic design, or software portion of the application. The employee remains the author and cannot assign the moral rights in the work. Moreover it is doubtful whether the employee may waive those rights.

International disputes are often complicated by choice of law, and transnational work-for-hire cases present many difficult issues. The smartphone game application example illustrates the differences among legal regimes, and raises the questions of whether: (1) a court will choose to apply U.S., French, or Indian law to issues of copyright ownership, the scope of rights in the work, the validity of the assignment, and infringement; and (2) the person who created the work is an employee or independent contractor. In great part, the answer to the choice of law question depends on the forum in which the case is brought. But, given all of the issues at play in a transnational infringement case of this sort, resort to dépeçage, in which the court applies different laws to different issues in the case, is probable.

A choice of law clause in an international agreement can be an effective way to ensure the application of a particular country's laws. Yet, whether the U.S. work-for-hire doctrine determines authorship, ownership, and transfer of rights if a work is created by an employee or independent contractor in another country, even with a well-crafted choice of law remains uncertain. Problems relating to authorship and

137 In the context of work-for-hire, issues of joint authorship become complicated. In the absence of an agreement to the contrary, all joint authors will equally share in the ownership of the joint work. Nimmer, supra note 5, at $\S \S 6.07[\mathrm{D}]$ and 6.08 . 
ownership of copyright for purposes of U.S. conflict of laws are not well understood and it may not be possible to adequately address them in a contractual clause. ${ }^{138}$

Questions of which law will govern the transfer of a copyright interest is one of the most volatile conflict of law issues in international copyright. ${ }^{139}$ Although parties are generally free to choose the law that will govern their contract, the choice is always subject to the conflict of law rules of the forum. European and U.S. courts favor enforcing the law chosen, on grounds of party autonomy or freedom of contract, subject to public policy considerations. ${ }^{140}$

A contractual choice of law may not be effective in international licensing and assignment agreements due to the overriding copyrightrelated public policy concerns in a particular forum. The copyright law of a country in which protection is sought may supersede the terms of a contract, particularly if the parties have attempted to transfer inalienable rights, such as moral rights. ${ }^{141}$ When a conflict arises between the copyright law of the forum and the law governing the contract, copyright law generally prevails. ${ }^{142}$

The national treatment standard required under international law provides guidance on which law applies to infringement. A work created in a Berne Convention or TRIPS signatory country infringed in the United States receives the same protection as any U.S.-created work. The law of the forum applies to infringement within the forum.

No such international harmony exists concerning which law applies to questions of authorship, ownership, and transfer of rights. ${ }^{143}$ While many countries will look to the law of the forum to answer these questions, courts in other countries will look to the country of origin or the country

138 Douglas E. Phillips, International Software Outsourcing $§ 17.02[\mathrm{~B}]$, in Drafting Licensing Agreements (Michael A. Epstein \& Frank Politano, eds. 2013).

139 GoldSTEIN AND HUGENHOLTZ, supra note 32, at $\$ 4.4$.

140 Paul Edward Geller, International Copyright: The Introduction §6[3][b]i], in InTERnational COPYRIGHT LAW AND PRACTICE (Paul Edward Geller and Lionel Bently eds. 2013); Regulation 593/2008 of the European Parliament and of the Council of 17 June 2008 on the Law Applicable to Contractual Obligations (Rome 1),2008 O.J. (L 177) 6.; American Law Institute, RESTATEMENT (SECOND) CONFLICT OF LAWS, $\S \S 186-188$ (1988 revision) (criteria applicable to contracts).

141 Goldstein AND HugenHOLTZ, supra note 32, at $\S 4.4 .2$.

142 Ibid. at $\S 4.4 .3$.

143 Ibid. 
having the closest connection to the work to answer questions of authorship and initial ownership. ${ }^{144}$

In the United States, issues of ownership and of substantive rights related to infringement are bifurcated into different conflict of law analyses. Courts generally determined ownership according to the law of the country with the most significant relationship to the property and parties, while deciding issues of infringement and remedies by the laws of the country where the infringement is alleged to have occurred. This rule was first articulated by the Second Circuit in Itar-tass Russian News Agency v. Russian Kurier, Inc. ${ }^{145}$ The Court noted that U.S. copyright law contains no relevant conflict of law rules ${ }^{146}$ and that previous courts had applied the work-for-hire doctrine without explicitly considering the conflict of law issues. ${ }^{147}$

The Second Circuit established, as a matter of federal common law, a choice of law rule for determining copyright ownership based on the Restatement (Second) of Conflict of Laws. The party's property interests are determined by the law of the state with "the most significant relationship" to the property and the parties. ${ }^{148}$ Applying the rule, the court determined the work's "country of origin" was the appropriate law to apply in determining ownership of a work created by a foreign national and first published in its home country. ${ }^{149}$ The court applied Russian law to determine whether the works were owned by the plaintiffs ${ }^{150}$ and U.S. copyright law to govern issues of infringement and remedies. ${ }^{151}$ Subsequent courts have followed this approach, applying foreign law to determine authorship or ownership. If the work is created by a foreign national and first published in a foreign country, then that is the country with the most significant relationship and the law of that country will be applied. ${ }^{152}$

\footnotetext{
144 Ibid.

145153 F.3d 82 (2d Cir. 1998).

146 Ibid. at 90.

147 Ibid. at 88-89 (citations omitted).

148 Ibid. at 90 (citing RESTATEMENT (SECOND) OF THE CONFLICT OF LAWS $\S 222)$.

149 Ibid.

150 Ibid. at 92.

151 This is consistent with the Berne Convention regime conditioning choice of law in infringement in cross border cases on where the infringement occurred. Geller, supra note 139, at §6[3].

152 Fahmy v. Jay-Z, 788 F.Supp. 2d 1072 (C.D. Cal. 2011); Lahiri v. Universal Music and Video Distribution, Inc., 513 F. Supp. 2d 1172, 1176 (C.D.
} 
The impact of Iter-Tass on software-based copyrighted products created with globally distributed teams is both considerable and unclear. The Second Circuit acknowledges that for purposes of conflict of laws, "ownership and infringement issues will not always easily be made."153 The most difficult cases are those in which the cases involve questions not only of ownership, but of the nature of the ownership interest, ${ }^{154}$ such as works created by multinational teams that may or may not be subjected to work-for-hire doctrine. ${ }^{155}$

The nationality of the person creating the work has been important in U.S. cases. The nationality of employer and where the work is first published may make a difference as well. "Insofar as the copyright ability of a work turns on the nationality or domicile of its author" the work-for-hire provision "may mean that the employer's nationality or domicile is determinative." 156 The work at issue in Itar-Tass was not first published in the United States nor had it been registered with the U.S. Copyright Office. The Second Circuit did not consider the interrelationship of foreign copyright law and the Copyright Act's presumption of validity for a timely registered work. ${ }^{157}$ The law on this interrelationship is unclear. Given that a U.S.-based company will likely first publish its game application in the U.S. and register the work, the presumption of validity may be difficult to overcome.

Once the question of ownership has been decided, the next question is whether the work has been assigned. The Itar-Tass court did not clarify choice of law issues concerning the assignment of rights. ${ }^{158}$ Nimmer suggests that the law of the country with the "most significant relationship" to the property and parties should also apply to assignments and licenses. ${ }^{159}$ This may be what U.S. courts are tacitly doing. In Saregama India Ltd., the Eleventh Circuit assumed, without deciding the issue, that Indian law governed both the ownership and the transfer of rights in that

Cal. 2007); Saregama India Ltd. v. Mosley, 687 F. Supp. 2d 1325,1334 (S.D. Fla. 2009), aff'd 635 F. 3d 1284, 1290 (11 th Cir. 2011).

$153 \quad 153$ F.3d at 91.

154 NIMMER, supra note 5 , at $\$ 17.05[\mathrm{~B}][2]$.

155 Geller, supra note 140 , at $\$ 6[2][\mathrm{b}] \mathrm{ii}]$ (noting that joint or collaborative works and those created by collectives and teams also present difficult cases).

156 NIMMER, supra note 5, at $\$ \$ 5.03[\mathrm{~A}]$ and 5.10[A].

157 See 17 U.S.C. \$ 410(c); Seoul Broadcasting v. Young Min Ro, 784 F. Supp. 2d 611, 614-15 (E.D. Va., 2011) (finding that the nature of evidence of foreign law submitted did not overcome the presumption of validity in 17 U.S.C. $\S 410(\mathrm{c}))$.

$158 \quad 153$ F.3d at 91 , fn 11.

159 NIMMER, supra note 5, at $\$ 17.05[\mathrm{~B}][2]$. 
case. ${ }^{160}$ The composer was Indian, the work was first published in India, and the agreements governing transfer of ownership provided that Indian law governed. In actuality, the case contained no conflict of laws issues since the result would have been the same under either Indian or U.S. law. ${ }^{161}$ The court set down no rules for determining which law would govern in the event of an actual conflict of foreign laws. These issues have yet to arise or be resolved in a reported case concerning outsourcing software or computer-based applications using distributed work forces.

\section{CONCLUSION}

Companies recognize the benefits of incorporating employee and contractor talent from across the globe to create copyrighted works. They may not always appreciate the pitfalls that exist, as well. A carefully drafted choice of law clause in employment and contractor agreements designating U.S. law will not be enough to ensure ownership and control. It remains an open question which law a U.S. court will apply to determine issues of authorship for portions of the work created abroad.

Although most countries do not recognize corporate authorship, it is possible for a legal entity to obtain ownership in the economic aspects of employee works in most jurisdictions. This may be accomplished either by operation of law or by using assignment agreements that meet the requirements of host country law. In jurisdictions such as Germany, following a monistic theory of copyright, such ownership by an employer is never possible since assignments are prohibited. Given the inability of the international community to reach accord on how to define author and initial owner, and that the U.S. perspective on corporate ownership is at odds with many legal traditions, it is unlikely that this area will achieve harmony. Recognition of moral rights in many countries will remain an obstacle to applying U.S. work-for-hire rules in jurisdictions in which they cannot be assigned or waived.

This is an area of law in which international harmonization does not exist and is unlikely to occur. Therefore, understanding the contours of copyright laws in each country in which a person is hired to create or contribute to a copyrighted work is essential. If a company wants to ensure ongoing ownership and control over works created by globally distributed teams, it must take care to outsource the work to countries where the laws support that control.

160635 F. 3d 1284 (11th Cir. 2011).

161 Ibid. at 1292. 


\section{BIBLIOGRAPHY}

\section{Treaties and International Conventions}

Agreement on Trade-Related Aspects of Intellectual Property Rights, Apr. 15, 1994, Marrakesh Agreement Establishing the World Trade Organization, Annex 1C, 1869 U.N.T.S. 299; 33 I.L.M. 1197 (1994).

Berne Convention for the Protection of Literary and Artistic Works, Sept. 9, 1886, as revised at Paris on July 24, 1971 and amended in 1979, S. Treaty Doc. No. 99-27 (1986).

\section{Statutes and Codes}

The Berne Convention Implementation Act of 1988, Pub. L. No. 100-568, 102 Stat. 2853.

C. DE LA PROPRIÉTÉ INTELLECTUELLE [CPI] Art. L.121-2, Art. L.122-6 (Fr.).

The Copyright Act, No. 14 of 1957; India Code (1957) (India).

Copyright, Designs and Patent Act, 1988, c. 48, (U.K.).

Copyright Law of the People's Republic of China (中华人民共和国著作权法), (promulgated by the Standing Committee of the Eleventh National People's Congress, Feb. 26, 2010, effective Apr. 1, 2010)(China) available at http://www. wipo.int/wipolex/en/text.jsp?file_id=186569).

Council Directive 1991/250/EEC of May 1991 on the Legal Protection of Computer Programs, 1991 O.J. (L. 122) 42.

Directive 2001/29/EC of the European Parliament and of the Council of 22 May 2001 on the Harmonisation of Certain Aspects of Copyright and Related Rights in the Information Society, 2001 O.J. (L. 167) 10.

Directive 2014/26/EU of the European Parliament and of the Council on Collective Management of Copyright and Related Rights and Multi-territorial Licensing of Rights in Musical Works for Online Use in the Internal Market, 2014 O.J. (L. 84) 72.

Gesetz über Urheberrecht und verwandte Schutzrechte [Urheberrechtsgesetz] [Copyright Act], Sept. 09, 1965, BGBl. I S. at 1273 (Ger.).

Regulation 593/2008 of the European Parliament and of the Council of 17 June 2008 on the Law Applicable to Contractual Obligations (Rome 1), 2008 O.J. (L. 177) 6.

United States Code, Copyright Act of 1976, 17 U.S.C. $\$ \S 101$ et seq. (2012)

The Visual Artist Rights Act of 1990, Pub. L. No. 101-650 (codified as amended in scattered sections of 17 U.S.C.).

\section{Cases}

Burrow-Giles Lithographic Co. v. Sarony, 111 U.S. 253 (1884).

Community for Creative Non-Violence v. Reid, 490 U.S. 730 (1989).

Cour de cassation [Cass.] [supreme court for judicial matters] Jul. 12, 2006, Bull. civ., No. 5-15472 (FR).

Fahmy v. Jay-Z, 788 F.Supp. 2d 1072 (C.D. Cal. 2011).

Itar-tass Russian News Agency v. Russian Kurier, Inc., 153 F.3d. 82 (2d Cir. 1998). 
Lahiri v. Universal Music and Video Distribution, Inc., 513 F. Supp. 2d 1172 (C.D. Cal. 2007).

Morris v. Business Concepts, Inc., 283 F.3d 502 (2d Cir. 2002).

Saregama India Ltd. v. Mosley, 687 F. Supp. 2d 1325 (S.D. Fla. 2009), aff'd 635 F. 3d 1284 (11th Cir. 2011).

Seoul Broadcasting v. Young Min Ro, 784 F. Supp. 2d 611 (E.D. Va. 2011).

\section{Secondary Sources}

Bently, Lionel and William R. Cornish, United Kingdom, in INTERNATIONAL COPYRIGHT LAW AND PRACTICE (Paul Edward Geller and Lionel Bently eds. 2013).

Buckman, Deborah F., Annotation, Intellectual Property Rights in Video, Electronic, and Computer Games, 7 A.L.R. Fed. 2d 269 (2005).

Dietz, Adolf, Germany, in InTERnational Copyright LAW AND Practice (Paul Edward Geller and Lionel Bently eds. 2013).

Dratler, Jay, JR. AND STEPHEN M. MCJOHn, InTEllectual PROPERTY LAW: COMMERCIAL, CREATIVE, \& INDUSTRIAL PROPERTY (Lslf. ed. 2013).

Ehrlich, Marc. A., Fair Use or Foul Play? The EC Directive on the Legal Protection of Computer Programs and Its Impact on Reverse Engineering, 13 PACE L.REV. 1003 (1994).

Epstein, Michael A. and Frank L. Politano, Drafting Licensing Agreements (2002, 2003 SUPPLEMENT).

Fisk, Catherine L., Authors at Work: The Origins of the Work-for-Hire Doctrine, 15YALE J. L \& HUMAN. 1 (2003).

Gangjee, Dev and S. Ramaiah, India, in INTERNATIONAL COPYRIGHT LAW AND PRACTICE (Paul Edward Geller and Lionel Bently eds. 2013).

Geller, Paul Edward, International Copyright: The Introduction, in INTERNATIONAL COPYRIght LAW AND PRACTICE (Paul Edward Geller and Lionel Bently eds. 2013).

Goldstein, Paul and P. Bernt Hugenholtz, International Copyright: PrinCIPLES, LAW, AND PRACTICE (3d ed. 2012).

Hong, Xue and Guo Shoukang, China, in InTERnational COPYRIGHT LAW AND PRACTICE (Paul Edward Geller and Lionel Bently eds., 2013).

INDIA: A HANDBOOK OF COPYRIGHT LAW (Government of India Ministry of Human Resource Development) (1999), available at http://www.wipo.int/wipolex/en/text. jsp?file_id=208016.

Hayes, Benjamin S., Integrating Moral Rights into U.S. Law and the Problem of the Works for Hire Doctrine, 61 OHIO ST. L. J. 1013 (2000).

André, Lucas, Pascal Kamina and Robert Plaisant, France, in INTERNATIONAL COPyright LAW AND PRACTICE (Paul Edward Geller and Lionel Bently eds. 2013).

LUCAS-SCHLOETTER, AgNÈS, LES DROITS D'AUTEUR DES SALARIÉS EN EUROPE CONTINENTALE, (Cahiers de l'IRPI, No. 5, 2004).

Millstein, Julian S., JefFrey D. Neugurger and JefFry P. Weigard, Doing BUSINESS ON THE INTERNET: FORMS AND ANALYSIS (Lslf. ed. 2013).

NefF, Richard E. AND Fran SMALlson, NAFTA: PROTECTING AND ENCOURAGing INTELLECTUAL PROPERTY RIGHTS IN NORTH AMERICA (1994).

Nimmer, Melville B. AND DAvid Nimmer, Nimmer on COPYRight (Lslf. ed. 2013). 
Ochoa, Tyler T., Who Owns an Avatar? Copyright, Creativity, and the Virtual World, 14 VAND. J .ENT. \& TECH. L. 959 (2012).

Oman, Ralph, Berne Revision: The Continuing Drama, 4 Fordham InTELl. Prop., MEDIA \& ENT. L. J. 139 (1993).

Palmer, Alan K. and Thomas C. Vinje, The EC Directive on the Legal Protection of Computer Software: New Law Governing Software Development, 2 DuKE J. COMP. \& INT'L. L. 65 (1992).

Phillips, Douglas E., International Software Outsourcing, in DRAFTING LicEnSING AGREEMENTS (Michael A. Epstein and Frank Politano, eds., 2013).

Rajan, Mira T. Sundara, Moral Rights: Principles, Practice and New TECHNOLOGY 295 (2011).

RESTATEMENT (SECOND) CONFLiCT OF LAWS, vol. 1 (1988 revision).

Saikia, Nandita, Indian Law: Getting Moral Rights Waived (July 15, 2012), available at http://copyright.lawmatters.in/2010/07.

Tober, J. Patrick and Shawn C. Helms, The "Work For Hire" Doctrine Almost Never Works in Software Development Contracts, METROPOLITAN CORP. Couns.10 (June 2008).

WOLK, SANNA and Christine Kirchberger, OWNERSHIP OF THE COPYRIGHT IN WORKS AND THE PATENT Right IN INVENTIONS CREATED By EMPLOYEES: IN FinLAND, Sweden, Germany, Austria, the United Kingdom, Estonia And ARgentina (2002). 